\title{
界面活性剤の新しい機能
}

\author{
浜中 博 義 \\ 東邦化学工業 (株) 界面活性剂研究所 \\ （東京都葛飾区東四ツ木 2-21-13）
}

\section{New Functions of Surfactants}

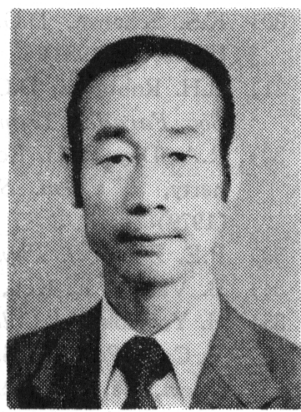

\author{
Hiroyoshi Hamanaka
}

Surfactant Research Laboratory, Toho Chemical Industry Co. (21-3, 2-chome, Higashiyotsugi, Katsushika-ku, Tokyo)

\section{1 はじめに}

極性基と非極性基の両方が分子内で適当な均衡を保っ て共存している界面活性剂は, そのために, 単一相, 多 相のいずれの系へ添加された場合にも良く相溶し, 乳 化性, 分散性, 起泡性, 浸透性, 吸着性及び配向性等の 通常言われる界面活性能を発揮する。そして, 少量の添 加で目的の性能を出し得るという長所がコスト面の上㫒 をほとんど伴わずに作業性を改善できる有益な手段とし て認識され, 繊維, 紙, 金属, 機械, 石油, 農業, 肥 料, 土木建築, 塗料, インキ, プラスチックから化粧 品, 食品, 医薬品に至る産業界の大半の分野での生産及 び使用時の有用な添加剤となり, 今日まで多く貢献して きている。社会は多様化と複合化の時代に突入し, 一方 で資源の枯渴が心配されている現在, 界面活性剤にさら に新しい機能を要求する声も増している1》。

それにこたえるには，新しい界面活性剤を合成した時 にその構造が示す固有な性質をいち早く見いだすことに 心がけると共に, 従来加ある界面活性剂の性質につい てもより深く追求し, 積極的に他の分野への応用をはか るべく努力することであると考えている。

以下に，これまでの分野での研究成果等を抢り込みな がら，機能性添加剤として工業的に利用されつつある界 面活性剤の興味ある例を二, 三紹介する。

\section{2 界面活性能を同時に必要とするもの}

界面活性剤をある目的のために機能性添加剤として使 用する際, そのもの自身のもつ界面活性能も同時に必要 とされる場合と, むしろ界面活性能が減衰した状態が望 ましい場合と, 界面活性能の有無に はほとんど関係しない場合の三つに 分類される。はじめに, 界面活性能

$$
\mathrm{CH}_{2}=\mathrm{CH}-\underset{\mathrm{CH}}{\mathrm{CH}}-\mathrm{CH}_{2}+\mathrm{NaOH}
$$

を同時に必要とする機能性添加剤について述べる。

\section{$2 \cdot 1$ 機能発現型添加剂}

界面活性剤構造よりなる化合物が新機能を有するもの である, いわゆる機能発現型添加剤の例としては, 相閒 移動触媒, ミセル触媒等の触媒が代表に挙げられる。

それらについては, 幾つかの成書及び総説 ${ }^{22 \sim 67}$ がある ので，詳しい説明は省くが，これまでに実際の工業面で 利用されてきた相間移動触媒としては, Starks が八口 ゲン置換反応での機構を示したテトラブチルアンモニウ ム=ブロミド (TBAB) のような対称構造の第四級アン モニウム塩型カチオン界面活性剂が圧倒的に多く ${ }^{2)}$, 医 薬, 農薬, 香料等の製造に幅広く用いられている。

置換反応では，ベンジル基を有する第四級アンモニウ 么塩は TBAB のような対称構造のテトラアルキル基よ りなる第四級アンモニウム塩に比べて, 触媒性能はやや 劣っているようであるが㐫，ベンジル基と長鎖アルキル 基をもつ, 乳化, 分散性の良いベンザルコニウム塩型の カチオン界面活性剤が下記に示した 3,4-ジクロロ-1-ブ テン (3,4-DCB-1) から 2-クロロブタジエン (2-CB) を導く脱離反応の触媒として有効であり, 実際に, 不燃 性のクロロプレンゴムの製造に扔けるモ/マー取り出し 工程での生産性向上でむ大いに役立っている9”。

この場合, ベンザルコニウム塩を使用すると, 反応効 率が良くなるだけでなく, Markovnikov の法則に基づ く脱離がより正確に行われるので, 副生成物の 1-ク口 ロブタジエンの混入が少なくなり，良質なゴムができる といら長所がもたらされる。

一方, ミセル触媒の工業的な応用としては, ポリエス テル, 綿などの風合改良を行うジョーゼット加工やシル 
ケット加工の促進剤がある ${ }^{10), 11)}$ 。例えば，ポリエステ ル繊維のアルカリ隇量加工について述べると，次のよう な処理条件の下でベンジルドデシルジメチルアンモニウ ムンクロリド (LDMBAC) と TBABをそれぞれ添加 して, 実施した結果を 表-1 に示したが, 界面活性能の 大きい LDMBAC の方が TBAB より数段性能が勝っ ており，実際面での作業性の改善にも大いに役立ってい る。

重量比; ポリエチレンテレフタラートタフタ : $1 \%$

$\mathrm{NaOH}$ 水溶液 $=1: 85$

触媒添加量 $; 0.05 \% ， 0.10 \%$ (対 $1 \% \mathrm{NaOH}$ 水溶 液)

反応温度及び時間 ; $95^{\circ} \mathrm{C}, 30 \mathrm{~min}, 60 \mathrm{~min}$

処理液の回転速度 ; $30 \mathrm{rpm}$

表-1 ポリエステル㵶維の減量率

\begin{tabular}{|c|c|c|}
\hline 使＼cjkstart用 & $\begin{array}{c}95^{\circ} \mathrm{C}, 30 \mathrm{~min} \\
\text { 処 }{ }^{3} \text { 理 }\end{array}$ & $\begin{array}{c}95^{\circ} \mathrm{C}, 60 \min \\
\text { 処 }\end{array}$ \\
\hline 触 媒 無 添 加 & $0.5 \%$ & $1.8 \%$ \\
\hline LDMBAC $0.05 \%$ 添加 & 9.0 & 20.0 \\
\hline " $0.10 \%$ 添加 & 17.0 & 33.8 \\
\hline $0.05 \%$ 添加 & 3.2 & 4.1 \\
\hline $0.10 \%$ 添加 & 3.6 & 4.6 \\
\hline
\end{tabular}

ただし，減量率二 $\frac{\text { 初期重量一処理後重量 }}{\text { 初期重量 }} \times 100$ である。

ミセル触媒の繊維工業へのもら一つの応用である綿の シルケット加工では, 精練工程と組み合わせる必要もあ って，アニオン䛺面活性剤も使用されている ${ }^{12)} 。$

なお，相間移動触媒の研究では，前述の第四級アンモ ニウム塩型カチオン界面活性剤のほかに, 第四級ホスホ ニウム塩型カチオン界面活性剤 ${ }^{7}$, 界面活性クラウンエ 一テル ${ }^{132,14)}$ 等の非イオン界面活性剂, アミンイミド型 の半極性界面活性剂 ${ }^{15)}, \alpha, \omega$-型雨性界面活性阂 ${ }^{16)}$ など が報告されているが,高価なこともあり,実用化されてい ない。相間移動触媒の特異な例では, 筡者らが先ごろ合 成した $\alpha, \omega$-型カチオン界面活性剤のベンジル $\left\{\omega-\left[N^{\prime}-\right.\right.$

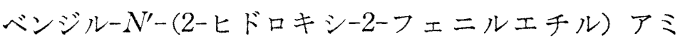
ノ]アルキル\}（2-ヒドロキシエチル）(2-ヒドロキシ-2フェニルエチル）アンモニウム=クロリド塩酸塩（化合 物 a) は水に不溶で, 界面活性能をほとんど示さず，八<smiles>Cc1ccccc1</smiles>

$\mathrm{HOCHCH}_{2}$

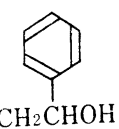

$\mathrm{CH}_{2} \mathrm{CHOH}$
$\mathrm{HOCH}_{2} \mathrm{CH}_{2}-\mathrm{N}^{-}\left(\mathrm{CH}_{2}\right)_{n}-\mathrm{N} \cdot \mathrm{HCl}$<smiles>ClCc1ccccc1</smiles><smiles>Cc1ccccc1</smiles>

(化命物 a)

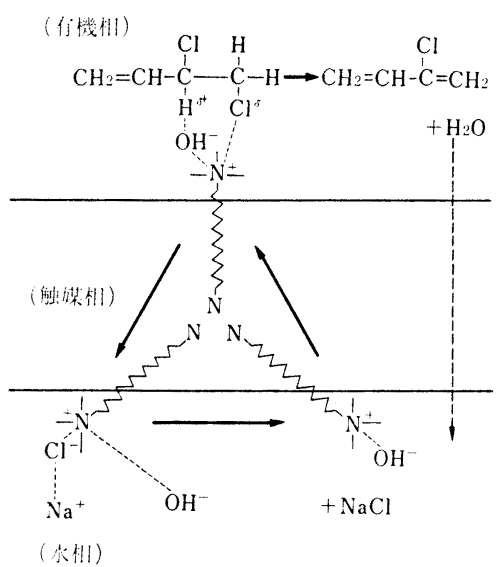

図-1 $\alpha, \omega$-型刃チオン界面活性剤の触媒機構

ロゲン置換反応の相間移動触媒やポリエステルの減量加 工注けるミセル触媒的機能を全く有しないが，前述の 3,4-DCB-1 から 2-CB をつくるような脱離反応の触媒 としてのみ選択的に作用するということがわかった ${ }^{17) 。 ~}$

この場合の触媒機構としては, Regen の提唱した三 相界面反応の固定化触媒に近いかたちで化合物 a が有 機相と水相の間に存在し18)，第四級アンモニウム基の部 分が水相側で $\mathrm{Cl}^{-}$イオンを $\mathrm{OH}^{-}$イオンと交換した後, 有機相側で, 図-1 のような四点中心型の遷移状態式を 通して 3,4-DCB-1 から $\mathrm{H}$ と $\mathrm{Cl}$ を同時に引き抜くも のと推定される。

\section{$2 \cdot 2$ 機能付与型添加剤}

界面活性剂構造に対してもら一つ別の機能をもつ原子 団，または基を連結させた機能付与型添加剤としては， 例えば，イオン型もしくは非イオン型界面活性剤にビニ ル基,アリル基, アクリル基, メタクリル基等の重合反応 性基を連結させた構造の反応性界面活性剂がある ${ }^{197,20) 。 ~}$ それらを乳化重合鼡として使用すると，原料モノマーと 結合して, 安定なエマルションを導くが, 同時に, でき 上がった高分子製品からのブリードがなくなるために， 耐熱性，耐水性の改善に役立つ。

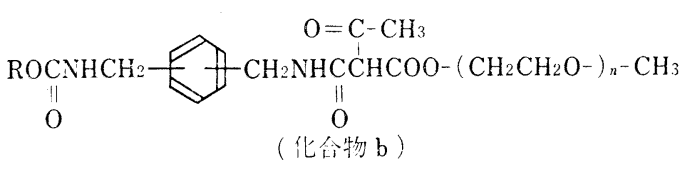<smiles>CCCC1COC(C)(C)O1</smiles>
(化命物 c)<smiles>C=C[SiH](C)C</smiles>

(化合物 d) 
また耐水性の改善では，所期の目的に使用後，界面活 性能が失われた方が良い場合があり，分解性界面活性剂 が望まれている。最近の報告では, 入道らの合成したブ ロック化イソシアナート型の熱分解性界面活性剤（化合 物 b ${ }^{21)}$ や Jaeger らの合成した酸分解性の界面活性剂 (化合物 c) がある22)。また，Yamauchi らの合成した スルホニウム塩（化合物 d) はアルカリ条件下で分解し て，メチル化試薬として作用するものであり，反応原料 になる界面活性剤ということで, さらに興味樑い23)。

一方, 染料の乳化分散には古くから界面活性剤が使わ れているが，Imae らは染料自身が界面活性能を有する もの（化合物 e）を合成しており年，これも一種の機能 付与型添加剤と見ることができる。

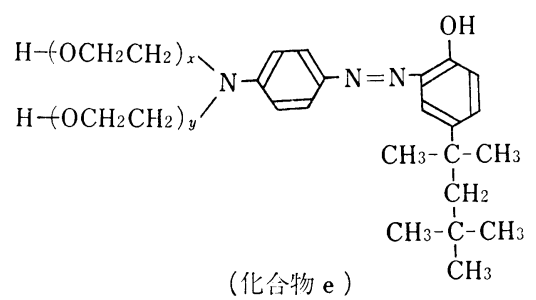

\section{3 機能代替及び機能補助型添加剤}

ソルビタン脂肪酸エステル (Span) やモノグリセリド は古くから食品乳化剤としてパンやクリームの製造に用 いられてきたが, Chung らは先ごろショ糖脂肪酸エス テルやエトキシ化モノグリセリドが製パン材料の小麦粉 脂質に一部代替し得るといらことを調べている ${ }^{25)}$ 。川島 らは本来, バクテリアの栄養となるポリオキシエチレン ソルビタン脂肪酸エステル (Tween) をカーバマート系 の農薬と共に使用すると, 殺菌力が増強されるというこ とを調べており ${ }^{26)}$ ，その組み合わせでは，Tween は機 能補助型の添加剤として作用している。

一方, 界面活性剂と水溶性高分子の混合系の諸性質に 関する研究も以前から行われており 27),28), 新しいとこ ろでは，アニオン界面活性剤の 2-スルホナト脂肪酸メ チル=ナトリウムや非イオン界面活性剤のドデシル =ポリ オキシエチレンニエーテルの水溶液中へポリビニルアル コールを添加した時の溶液粘度の変化や可溶化能に対す

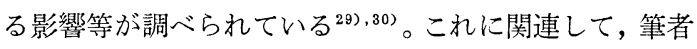
らは逆にポリビニルアルコールの水溶液中に半極性界面 活性剤のジ（グリセリン）ボラート・エチレンオキシド 付加体の脂肪酸エステル（化合物 F) を添加した系につ いて, 水性接着郕としての性能を追求した。

その結果, ポリビニルアルコールの水溶液そのものに 比べて著しく初期接着性が向上し, かつ, 接着力も強ま ることがわかった ${ }^{31}$ 。これも機能補助型添加剤の一例で あろう。

また, 最近では, 石油の二次, 三次回収の必要から,

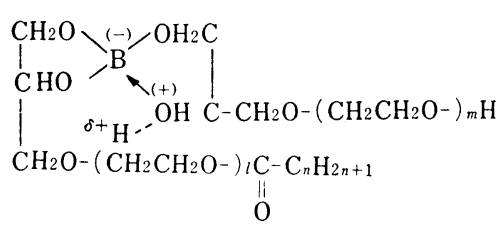

(化命物 $\mathrm{F}$ )

採油パイプを地下二，三千メートルの深さまでうめ込む ことが多くなっているが, その際, 嫌気性の硫酸還元菌 がつくり出す $\mathrm{H}_{2} \mathrm{~S}$ による腐食が問題になり, 現在, 力 チオン界面活性剤やある種のアルデヒドを殺菌剤として 使用したり，アミン類を腐食防止剤として添加すること が日タ行われている ${ }^{32}$ 。筆者らはモデル実験として $5 \%$ 食塩水溶液に $500 \mathrm{ppm}$ の $\mathrm{H}_{2} \mathrm{~S}$ を吸収させた腐食液と ケロシンとの間に界面をつくり，両相に溶ける新規な非 イオン界面活性剤の 1-ドデシル-4-メチル-3, 6,7,8-テ トラヒドロ-1,5-ジアゾシン-2-オン (化合物 G) ${ }^{33)}$ をそ れぞれ 30, 50, $100 \mathrm{ppm}$ 添加した後, JIS G-3439 号に 規定する $1^{\prime \prime} \times 1^{\prime \prime} \times 0.1^{\prime \prime}$ の継目無し鋼管を浸漬させ， 7 日間静置した時の防食率を調べた。また，嫌気性菌用液 体培地を使用して, 化合物 $\mathrm{G}$ の硫酸還元菌に対する抗 菌力を測定した。

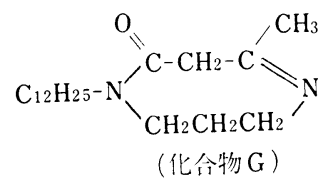

結果を 表-2 に示したが，化合物 $\mathrm{G}$ は腐食防止剤と しても, 殺菌剤としても有効であり，それぞれの機能を 相互に代替もしくは補助する複合型の作用薬剤として, 近い将来, 役立つものと期待している。

表-2 1-ドデシル-4-メチル-3,6,7,8-テトラヒドロ-1,5 ージアジシンー2-オンの腐食防止性と抗菌性

\begin{tabular}{|c|c|c|}
\hline 添加 量 & 防 食率a) & 硫酸還元菌b) の発育状態 \\
\hline $30 \mathrm{ppm}$ & $87.1 \%$ & \pm \\
\hline 50 & 90.0 & - \\
\hline 100 & 92.4 & - \\
\hline
\end{tabular}

a）防食率は 鋼管（ブランク）の重量減少一鋼管（添加郕 使用)の重量減少 $\times 100$ で計算した。

b）硫酸還元菌位, Desulfovibrio desulfuricans IFO-13699 文使用した。

\section{3 界面活性能の減衰を利用するもの}

これまでの例では, 界面活性剤を機能性添加剂として 使用するにあたり，そのもの自身のもつ界面活性能も大 、に必要とする場合が多かった。ここでは, 界面活性能 が弱められた状態で使われる機能性添加剤の例を示す。 金属めっきには, 光沢めっきのほかに, サテン状の表 
面をつくって光を拡散させるめっき法があるが, 從来, この種のものはなし地めっきと称し, めっき面に対して サンドブラスト, ブラッシング, ホーニングなどの機械 的処理を行うことが工程上必要であった。

このなし地めっきと同様の表面仕上がりをめっき浴の 中だけでなし得るようにしたのが，西独ヘンケル社で開 発されたベロアニッケルめっき法と呼ばれる新しいサテ ンめっき技術であり, 根本には, 界面活性剤の曇り点現 象が利用されている ${ }^{34)}$ 。すなわち, 硫酸ニッケル, 塩化 ニッケル, ホウ酸, サッカリンなどを溶解させた電解液 中に基礎光沢剤である $N$-アセチル-o-トルエンスルホ ンアミドと量り点 $20 \sim 30^{\circ} \mathrm{C}$ の非イオン界面活性剤を添 加して, はじめに, 量り点以下の温度で均一透明な溶液 をつくる。つづいて, 温度を高め, 液温を曇り点以上に した後, 被めっき材を投入すると, 生じた不透明粒子が カソード表面に付着したり, 離脱したり寸る閒に直径 2 〜30 $\mu \mathrm{m}$ のマークが次々と写し出され, サテンめっきが 完成する。

写真-1 に, 通常の光沢ニッケルめっき仕上げによる 成型物と非イオン界面活性剂のポリオキシエチレン=ポ リオキシプロピレン=エーテルを使用したサテンニッケ ルめっき仕上げによる成型物とを対比させて示した。本 例などは, 界面活性剤の一般的な性質を優れた機能とし て展開させた代表的なもので, 応用面での価值は高い。

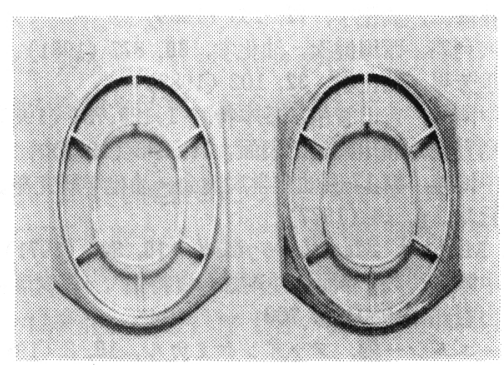

左側は光沢めっき仕上げによるものであり, 右側は非イオン界面活性剤を使用したサテン めっき仕上げによるものである。

写真-1 ニッケルめっき成型物

\section{4 界面活性能に無関係なもの}

合成繊維，プラスチックなどの静電気障害を取り除く ベく作用するものとしては, 各種のイオンもしくは非イ オン界面活性剤を応用した表面塗布型帯電防止剤及び内 部練り込み型帯電防止剤が古くから知られている ${ }^{85)}$ 。

また, 電子複写紙, 静電記録紙用の導電化剂では, ポ リ (ベンジルトリメチルビニルアンモニウム=クロリド) やポリ (スチレンスルホン酸) 等のイオン型の高分子界 面活性剂が用いられている ${ }^{36)}$ 。しかしながら，それらの ものの機能発現に際しては, 表面での吸着, 配向, ある いはまた, 内部から表面への移行というょうな界面活性
剂としての性質も少なからず必要であった。

最後に, 界面活性能にはほとんど無関係に作用する機 能性添加剤の一例として, 前二者と同じ電気特性改良剂 に属するプラスチックサーミスター助剤を選び, 説明す る。

プラスチックサーミスターは, 基剤となる熱可塑性樹 脂の中に導電キャリヤーを分子分散させることによって つくられるもので, 特に広い空間, 面積にわたっての平 均的温度の検知や複雑な面をもつものの表面温度の測定 に効力を発揮し, 現在, 電気毛布や火災報知機などで実 用化されている ${ }^{37)}$ 。図-2 は, その一つである十イロン サーミスターの内部構造を示したものであるが，感熱層 である 12-ナイロン中には導電キャリヤーとして相溶性 の良い非イオン界面活性剤が練り込まれており，その導 電性は大きな温度依存性を示す。温度の低い間は感熱層 の電気抵抗が高いために, ヒーター線に電流を流すと同 時に発熱するが, 温度が高くなると, 感熱層の抵抗值が 下がり, 導電性が増す。したがって, これを検知線に感 知させて, 即ヒーター入力に応答させるようにすれば, 電熱部材全体の温度を一定温度以上に上昇させない仕組 みができ上がる ${ }^{38)}$ 。

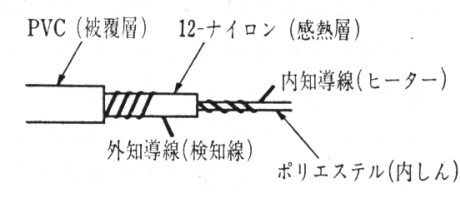

図-2 ナイロンサーミスターの内部構造

図-3 に, 2.3 で石油採油用殺菌剤兼腐食防止剤とし て紹介した化合物 Gを $3 \%$ 練り込んだ 12-ナイロンの インピーダンスー温度曲線を示したが, 温度の上昇と共に 導電性が増して行くのがわかる。このように, プラスチ ックを有機半導体へと変化させ得るものとしては, 同じ ように分子内に $\mathrm{C}=\mathrm{N}$ 結合を有するイミダジリン系の 化合物が他に知られている ${ }^{399}$ 。

こうして見ると, プラスチックサーミスターとしての

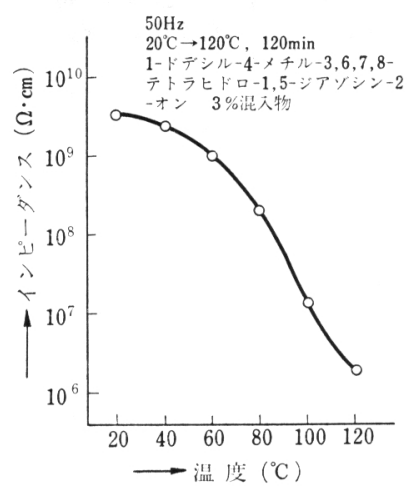

図-3 12-ナイロンのインピーダンスー温度曲線 
機能を满足させる添加剤は, 帯電防止剤や導電化剤のよ うに親水基の部分の電気伝導性がはじめから強いもので は用をなさないが，しかし極性基がなければ，導電性付 与というその役目を果たすことができない。また，絶え ず行われる熱変化の繰り返しに対しても基剤であるプラ スチックとの相溶性が損われず, 常に同一の電気特性一 温度曲線を再現しなければならないので，疎水基のよう な非極性部分も分子中にあった方が良い。したがって， この種の添加剤は界面活性能を利用して働くものではな いが，界面活性剤構造であることの必要性は大いにある と思われる。

\section{5 おわりに}

本稿では, 界面活性剤の応用研究の中から比較的新し い機能として取り上げられたものについて, 主として工 業的に利用されつつある化合物を中心に, 本来の性質で ある界面活性能と関連させながら解説したが, 冒頭に述 べたような多様化の時代は機能性添加剤についても例外 ではなく, 相間移動触媒として説明した TBAB が, 全 く異分野の新型電池電力貯蔵システム ${ }^{40)}$ の一つである鱼 鉛一臭素電池の機能妨げとなる 突起物の防止に 役立つこ となどが最近の報道に見られ ${ }^{411}$, 今後より一層幅広い目 をもたなければならないと痛感させられている。

今回は, 紙面の都合もあり, 化合物とその用途の紹介 にとどまったが，不充分な点についてはお詑びしたい。

なお，また機会があれば，専門の方々の御意見を承わ りつつ, 機能性添加剤としての界面活性剂の研究の取り 組み方や志向性についてまとめて見たいと考えている。

\section{（昭和 59 年 7 月 2 日受理）}

\section{文献}

1) 桑村常彦, 油化学, 31, 793 (1982)

2) W.P. Weber, G.W. Gokel, "Phase Transfer Catalysis in Organic Synthesis", Springer-Verlag, New York (1977)

3) C.M. Starks, C. Liotta, "Phase Transfer Catalysis", Academic Press, New York (1978)

4) 木瀬秀夫, 妹尾 学, 有合化, 35, 448 (1977)

5）太垣和一郎, 有合化, 36, 931 (1978)
6）小田良平, 表面, 17, 314 (1979)

7) C.M. Starks, J. Am. Chem. Soc., 93, 195 (1971)

8）福永公寿, 井手 茂, 森 道徳, 木村 允, 日化, 1977, 1379

9) J.B. Campbell, R.E. Tarney, US Pat., 3,981,937 (1976)

10）坂本 誠, 加工技術, 14, 6 (1979)

11）寺島治良, 南 悦夫, 竹下大三郎, 繊維, 18, 46 (1966)

12）橋本 昭, 加工技術, 18, 664 (1983)

13）桑村常彦, 河内映昌, 油化学, 28, 195 (1979)

14) P.L. Kuo, M. Miki, I. Ikeda, M. Okahara, J. Am. Oil Chem. Soc., 57, 227 (1980)

15) 亀山栄一, 油化学, 27, 197 (1978)

16）蒲康夫, 鈴木 洋, 油化学, 32, 480 (1983)

17）浜中博義, 後藤忠夫, 脇田雅元, 宍戸 隆, 第 20 回油化 学討論会・油化学研究発表会講演要旨集, p. 87 (1981)

18) S.L. Regen, J. Am. Chem. Soc., 97, 5956 (1975)

19）藤田 茂, 村山浩一, 金田豊人, 原田 享, 上田敏夫, 特許公告, 昭 $54-41543$

20）谷内 瞕, 佐伯周二, 鈴木直文, 特許公告, 昭 59-11331

21) 入道尊則, 中尾勝明, 南 悦夫, 油化学, 28, 909 (1979)

22) D.A. Jaeger, M.R. Frey, J. Org. Chem., 47, 311 (1982)

23) K. Yamauchi, Y. Hisanaga, M. Kinoshita, J. Chem. Soc., Perkin Trans. I, 1983, 1941

24) J. Imae, C. Mori, S. Ikeda, J. Chem. Soc., Faraday Trans. I, 78, 1359 (1982)

25) O.K. Chung, Y. Pomeranz, K.F. Finney, M.D. Shogren, J. Am. Oil Chem. Soc., 55, 635 (1978)

26) 川島和夫, 竹野恒之, 油化学, 31, 163 (1982)

27）丸田嚴, 日化, 83, 782 (1962)

28) 斉藤修二, 油化学, 12, 133 (1963)

29）須沢利郎, 西田健次, 油化学, 30,877 (1981)

30）岩垂芳男, 油化学, 32, 102 (1983)

31）浜中博義, 吉田智侑, 日本特許 $1,125,731$ (1983)

32）大島宣夫, 瀬川康雄, 表面, 21, 233 (1983)

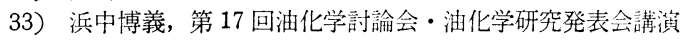
要旨集, p. 14 (1977)

34) G. Michael, Metalloberfläche, 10, 345 (1971)

35）浜中博義, “新界面活性剂総合資料集”, 経営開発セン夕 一出版部 (1980) p. 700

36) シーエムシー編, ファインケミカル, 10, 3 (1981)

37）山元一正, 下間 亘, プラスチックス, 20, 28 (1969)

38）竹内 正, 生田 達, 仲田勝晴, 工業材料, 25, 81 (1977)

39）下間 亘, 漕口 昭, 清水陦夫, 特許公告, 昭 46-10970

40）小沢文夫, 電子技術総合研究所彙報, 47, 571 (1983)

41）巨刊工業新聞, 昭和 58 年 5 月 3 日号 